
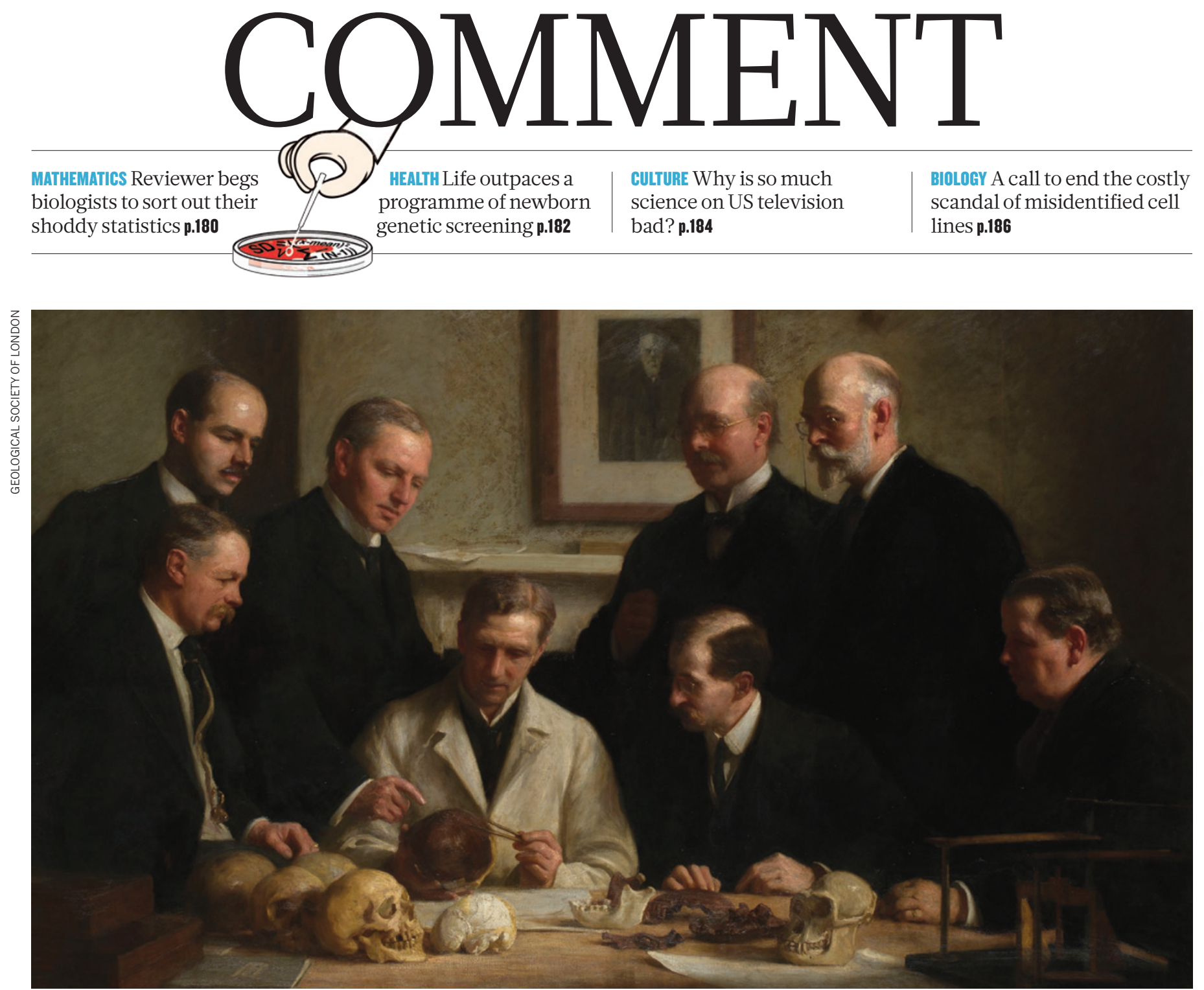

In John Cooke's painting Discussion on the Piltdown Skull (1915), scientists examine a human-like cranium found in Piltdown, England, in 1912.

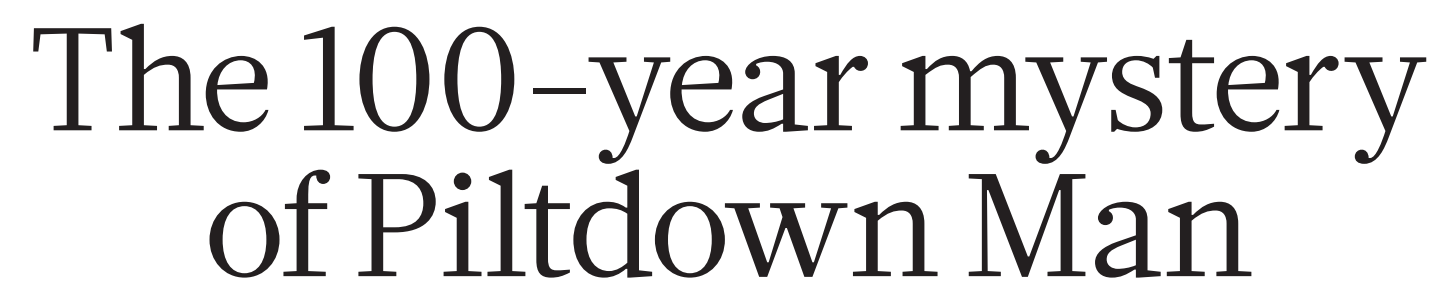

Chris Stringer explains why the longest-running whodunnit in palaeontology is still worth solving.

$\mathrm{N}$ ine years ago, the Natural History Museum in London, where I work, celebrated the 50th anniversary of the disclosure of one of the most successful scientific hoaxes in history. In 1953, scientists from the museum and the University of Oxford, UK, showed that specimens unearthed in the early twentieth century from the village of Piltdown in Sussex, UK, were an elaborate forgery - not evidence of a primitive human, as their discoverers had claimed in December 1912.

During our celebrations, a jaded colleague said: "I'd like to see the anniversary commemorated by the crushing of all the material and the burning of the Piltdown archive!" Yet, almost a decade later, I find myself part of a growing team of investigators hoping to reveal how the forgery was accomplished, and so to work out, finally, who did it and what drove them.

Why -100 years after 'Piltdown Man' was presented to the Geological Society of London - does it matter?

Personally, I am intrigued by the question of whether the hoax was driven by scientific ambition or by more jocular or vindictive motives. Also, the story has continuing relevance beyond its allure as a whodunnit: it is a warning to scientists to keep their critical guard up, and an example of the (eventual) triumph of the scientific method. In 1891, a Dutch palaeoanthropologist 

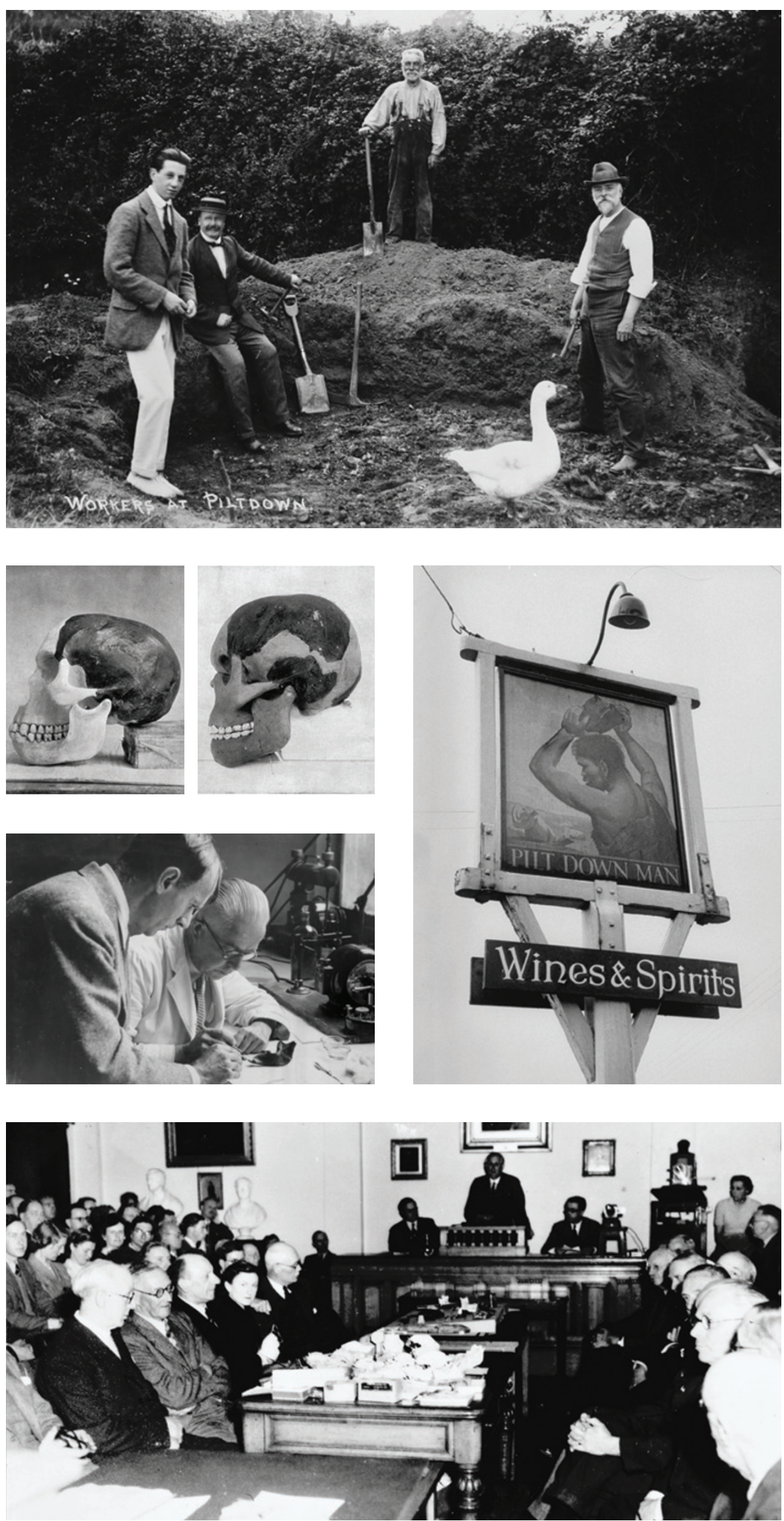

Clockwise from top: Charles Dawson (sitting) and Arthur Smith Woodward (right) at the Piltdown site around 1913; a local pub's homage to Piltdown Man; the forgery's extent is revealed in London, 1954; Kenneth Oakley (left) and L. E. Parsons examine Piltdown jaw, 1949; Eoanthropus skull models, 1913. described the first known specimens of Homo erectus ('Java Man'), which he had discovered in Indonesia. Sixteen years later, a workman in Germany unearthed the jaw of 'Heidelberg Man', a possible descendant of $H$. erectus. Thus it was with great pride that Arthur Smith Woodward and Charles Dawson announced on 18 December 1912 that they had found an even more remarkable fossil human at Piltdown ${ }^{1}$.

Woodward was a distinguished British palaeontologist and 'Keeper of Geology' at what was then the British Museum of Natural History; Dawson was an amateur antiquarian. What Woodward called Eoanthropus dawsoni ('Dawson's dawn man') consisted of an ape-like mandible containing two molar teeth and parts of a human-like cranium. Woodward and Dawson had also unearthed primitive stone tools and fragments of fossilized mammals, including a hippopotamus and an elephantlike creature - all stained the same dark brown as the gravels in the pit where they were found. The finds led Woodward and Dawson to assert that Eoanthropus was potentially as ancient as Java Man - now known to be about one million years old.

Excavations led by the pair over the next two years recovered more artefacts and fauna from the Piltdown site, including a canine tooth. Even a slab of elephant bone was dug up which, because of its shape, became known as the 'cricket bat'. Further work was disrupted by the onset of the First World War and Dawson's declining health. But before Dawson died in 1916, he wrote to Woodward saying that he had found further remains of fauna and Eoanthropus at a second site, a few kilometres from the original gravel pit.

\section{A COMPLEX FORGERY}

The discoveries made headlines throughout the world. But in palaeontological circles, reactions were mixed from the beginning. Several prominent British scientists fully accepted the existence of Eoanthropus. A minority joined some US and German researchers in questioning the association of the jaw and skull parts. They believed that an ancient ape fossil could have become mixed into deposits containing fragments of a more recent human skull. Some dissenters were won over by the tooth and skull fragments Dawson found at the second Piltdown location, which matched those from the first site.

Through the 1920s and 1930s, Eoanthropus was increasingly marginalized as other ancient humans were discovered in Africa, China and Indonesia. None of these fossils showed Eoanthropus' strange combination of ape-like jaw and human-like braincase.

By 1950, things had become even worse for Eoanthropus. Kenneth Oakley, a geoarchaeologist at the museum, applied chemical tests to the relics and determined 
WHO DID IT?

Four main suspects in the Piltdown case
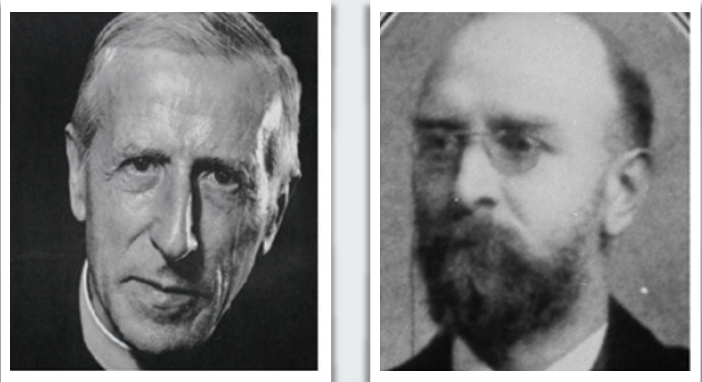

Arthur Smith Woodward Museum head of geology and co-leader of Piltdown finds.

canine tooth at Piltdown.
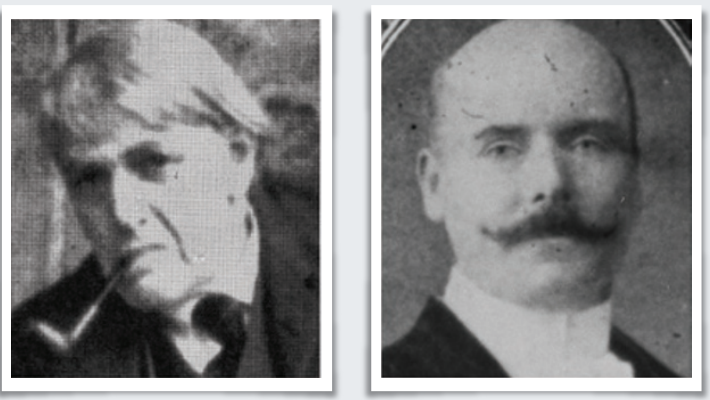

Charles

Dawson Ambitious fossil collector and co-leader of Piltdown finds.

that the jaw could not be more than 50,000 years old, even though some of the Piltdown fauna was clearly much older. More comprehensive studies by Oakley and his colleagues, published in 1953 and 1955, revealed the full extent of the forgery ${ }^{2,3}$.

A jaw and canine, probably from a modern orangutan, had been manipulated and stained, along with parts of a modern human skull. The fossil fauna had been gathered from many different places before being planted in the Piltdown gravels, and the stone tools had been similarly introduced after being stained to match the colour of the deposits. As for the 'cricket bat' - it had been carved with a steel knife from a fossilized elephant femur.

Once the truth was out and national embarrassment overcome, the hunt was on for the culprit(s) in a palaeontological mystery that persists to this day (see 'Who did it?'). Dawson was and is a prime suspect ${ }^{4-6}$. Woodward and at least 12 others have also been accused, singly or in combination (see go.nature.com/x8uboq).

My colleagues and I (at present, we are a team of 15 researchers from the Natural History Museum and several British universities) are now examining the finds at a microscopic level. Using techniques such as radiocarbon dating and DNA and isotope studies, we hope to pin down the taxonomic identities and geographical origins of the specimens. We are also using spectroscopy to establish how many different staining methods were applied to the Piltdown assemblages of bones, teeth and tools.

If the materials collected from the two sites match up, the culprit was likely to have been Dawson, as he was the sole 'discoverer' of the remains from the second site. If the canine turns out to have a different origin (and to have been stained differently) from the other samples, then its discoverer, Teilhard de Chardin, may have been involved in the $\mathrm{scam}^{7}$. De Chardin, then a novice Jesuit priest (later, a famous thinker and palaeontologist), helped Dawson in his work at the site.

Alternatively, our results could strengthen or refute another recently proposed scenario involving zoologist Martin Hinton ${ }^{8}$. At the time of the Piltdown discoveries, Hinton was a volunteer in Woodward's department at the museum. During the 1970s, more than a dozen modified and stained bones and teeth were found among Hinton's personal possessions (he died in 1961).

\section{MIXED BLESSING}

Identifying who doctored and planted the Piltdown assemblage is the key to understanding why they did so. If it turns out that Dawson was to blame, for instance, scientific recognition was almost certainly the driving force. Dawson had ambitions to become a Fellow of the Royal Society, and he clearly liked to cultivate relationships with important people.

It is unclear why Hinton would have played trickster. One possibility is that he surmised that something was amiss with the Piltdown findings but felt unable to raise his concerns to his department head (Woodward). Or perhaps he planted the 'cricket bat' (seemingly a far less sophisticated forgery than the other artefacts) as a

way to alert his colleagues ${ }^{9}$.

Regardless of who was responsible, the Piltdown hoax is a stark reminder to scientists that if something seems too good to be true, then perhaps it is. The hoax is unprecedented in its complexity (some of the Piltdown finds were more expertly modified than others, and the skill of the forger(s) is one of the aspects we are examining). But it is not the only example of trickery within palaeontological and archaeological circles. Indeed, what happened at Piltdown may well have sped the revelation, in 2000, that the famous Japanese archaeologist Shinichi Fujimura was burying stone tools he had collected in previous digs to later unearth them as fresh finds.

Piltdown Man's temporary ascendancy undoubtedly cost the field. For instance, it delayed widespread acceptance of Australopithecus africanus, an early hominin found in South Africa in the mid-1920s, as a genuinely ancient relic of human evolution.

Less obviously, Piltdown Man demonstrates the power of the scientific method to expose the truth, eventually (see go.nature.com/tbb9ma). The discoveries at Piltdown were steadily undermined by finds made elsewhere, even though the reasons for the specimens' failure to withstand scrutiny were not fully articulated until 1953. Indeed,

"It shows how far the field of palaeoanthropology has come in the past 100 years.' Piltdown Man's days were numbered once radiocarbon dating began to be routinely applied to the fossil record, from about 1959.

That the story of Piltdown Man still resonates today is understandable: as a 'real-life' whodunnit, it is hard to beat. Ultimately, however, it shows how far the field of palaeoanthropology has come in the past 100 years.

Chris Stringer is Research Leader in Human Origins in the Department of Earth Sciences, Natural History Museum, London SW7 5BD, UK.

e-mail:c.stringer@nhm.ac.uk

1. Dawson, C., Woodward, A. S. \& Smith, G. E. Q. J. Geol. Soc. Lond. 69, 117-152 (1913).

2. Weiner, J. S., Oakley, K. P. \& Le Gros Clark, W. E. Bull. Br. Mus. Nat. Hist. 2, 139-146 (1953).

3. Weiner, J. S. et al. Bull. Br. Mus. Nat. Hist 2, 225-287 (1955)

4. Weiner, J. S. \& Stringer, C. The Piltdown Forgery (Oxford Univ. Press, 2003)

5. Russell, M. Piltdown Man: The Secret Life of Charles Dawson and the World's Greatest Archaeological Hoax (Tempus, 2003).

6. McNabb, J. Archaeol. J. 163, 1-41 (2006).

7. Thackeray, J. F. Trans. R. Soc. S. Afr. 66, 9-13 (2011).

8. Gardiner, B. G. Zool. J. Linn. Soc. 139, 315-335 (2003).

9. Stringer, C. Homo Britannicus (Penguin, 2007) 